\title{
Metals and Neuronal Metal Binding Proteins Implicated in Alzheimer's Disease
}

\author{
Joana S. Cristóvão, ${ }^{1}$ Renata Santos, ${ }^{2}$ and Cláudio M. Gomes ${ }^{1}$ \\ ${ }^{1}$ Faculdade de Ciências Universidade de Lisboa, Biosystems and Integrative Sciences Institute and \\ Department of Chemistry and Biochemistry, Universidade de Lisboa, Campo Grande, 1749-016 Lisboa, Portugal \\ ${ }^{2}$ Development of the Nervous System, Institut de Biologie de l'Ecole Normale Supérieure (IBENS), INSERM U1024, \\ CNRS UMR8197, 46 rue d'Ulm, 75005 Paris, France \\ Correspondence should be addressed to Cláudio M. Gomes; cmgomes@fc.ul.pt
}

Received 5 November 2015; Accepted 17 December 2015

Academic Editor: Felipe Dal Pizzol

Copyright ( $) 2016$ Joana S. Cristóvão et al. This is an open access article distributed under the Creative Commons Attribution License, which permits unrestricted use, distribution, and reproduction in any medium, provided the original work is properly cited.

\begin{abstract}
Alzheimer's disease (AD) is the most prevalent age-related dementia affecting millions of people worldwide. Its main pathological hallmark feature is the formation of insoluble protein deposits of amyloid- $\beta$ and hyperphosphorylated tau protein into extracellular plaques and intracellular neurofibrillary tangles, respectively. Many of the mechanistic details of this process remain unknown, but a well-established consequence of protein aggregation is synapse dysfunction and neuronal loss in the AD brain. Different pathways including mitochondrial dysfunction, oxidative stress, inflammation, and metal metabolism have been suggested to be implicated in this process. In particular, a body of evidence suggests that neuronal metal ions such as copper, zinc, and iron play important roles in brain function in health and disease states and altered homeostasis and distribution as a common feature across different neurodegenerative diseases and aging. In this focused review, we overview neuronal proteins that are involved in $\mathrm{AD}$ and whose metal binding properties may underlie important biochemical and regulatory processes occurring in the brain during the $\mathrm{AD}$ pathophysiological process.
\end{abstract}

\section{Alzheimer's Disease: Hallmark Amyloid Aggregation and Neuronal Dysfunction}

Alzheimer's disease $(\mathrm{AD})$ is a progressive neurodegenerative disorder characterized by cognitive decline. The neuropathology hallmarks are gross atrophy of the cortex and hippocampus, and the accumulation of amyloid-beta $(\mathrm{A} \beta)$ into senile plaques and of hyperphosphorylated tau into neurofibrillary tangles. The deposition of $\mathrm{A} \beta$ and hyperphosphorylated tau aggregates in the human brain occurs in opposite directions with an orderly neuroanatomical pattern. Amyloid plaques first appear in the neocortex and slowly progress through the striatum, the basal cholinergic nuclei, the brain stem, and finally the cerebellum [1]. The deposition of tangles begins in the brain stem and progresses towards the neocortex [2]. Thus, the common presence of amyloid plaques and tau neurofibrillary tangles in the cortex only happens at late stages of the disease.
$\mathrm{AD}$ is heterogeneous and multifactorial with sporadic and familial forms [3-6]. The large majority of patients have the sporadic form or late onset dementia (later than 65 years). The few remaining patients have the familial form with early onset dementia (around 30 years to 65 years) and may present different symptoms. These patients have mutations in one of three genes encoding proteins essential for $\mathrm{A} \beta$ formation: the amyloid precursor protein (APP) and presenilins 1 and 2 (PSEN1/2) [7-10]. Presenilins are components of catalytic subunit of $\gamma$-secretase multicomplex, responsible for the cleavage of APP and formation of A $\beta$. The origin of the sporadic form is complex involving multiple genetic and environmental risk factors, for example, the presence of apolipoprotein E- $\varepsilon 4$ allele, mitochondrial dysfunction, head injury, or a compromised brain blood barrier [3, 11]. Despite the fact that $\mathrm{AD}$ is the most common form of dementia of the elderly and affects millions of people worldwide, the exact cause of this disorder is still unknown. The genetic evidence 
obtained from the rare familial form of $\mathrm{AD}$ supports the hypothesis that the accumulation of $A \beta$ plaques is at the origin of the disease. This is the foundation for the amyloid$\beta$ cascade hypothesis [12] which has been the central theory in $\mathrm{AD}$ research for the last three decades. According to this hypothesis, the deposition of $\mathrm{A} \beta$ is the initial event and it is sufficient to trigger the cascade of pathological and clinical changes in $\mathrm{AD}$, which are the formation of senile plaques and neurofibrillary tangles and subsequent neuronal death, vascular damage, and dementia [12]. Although senile plaque deposition is an early event in the disease, as observed in postmortem human brains [1], plaque accumulation in the brain does not correlate with dementia [13] implying that other mechanisms are associated with neurodegeneration. Notably, therapies designed until now that aimed at targeting amyloid plaques and APP proved to be largely unsuccessful. An increasing amount of data challenges the amyloid- $\beta$ cascade hypothesis.

Therefore, efforts to integrate the other pathogenic features of $\mathrm{AD}$ and multiple etiology pathways into a more global model are now needed. During the course of AD, tau is hyperphosphorylated and accumulates in the somatodendritic compartment as paired helical filaments and straight filaments [14]. In neurons, tau is the major microtubule associated protein and stabilizes its structure. Tau interacts with tubulin promoting its assembly into microtubules. The level of phosphorylation regulates the activity of tau and hyperphosphorylation suppresses its microtubule assembly activity. In addition, hyperphosphorylated tau sequesters normal tau and other microtubule associated proteins that further contribute to microtubule disassembly [15]. Therefore, the abnormal phosphorylation of tau results in loss of normal function and gain of toxic function in the AD brain. The formation of neurofibrillary tangles does correlate with cognitive decline and with neuronal and synapse loss $[13,16]$.

Senile plaques are extracellular deposits composed mainly of amyloid peptides ranging from 39 to 43 amino acids, which are natural metabolites of APP generated by sequential cleavage by $\beta$-secretase and $\gamma$-secretase 1 [17]. The APP is a transmembrane protein necessary for neurogenesis, for neurite outgrowth and guidance, and for synapse formation and repair [18]. APP is processed in different ways through different enzymes leading to the formation of amyloidogenic and nonamyloidogenic precursors. The processing of APP results in the formation of soluble $\alpha$ and $\beta$-secreted APP (sAPP) which is cleaved by $\alpha$ - and $\beta$ secretase, respectively. As a product in the nonamyloidogenic pathway, sAPP $\alpha$ promotes neuronal survival and neurite outgrowth, among other beneficial neuronal functions. Contrarily, $\operatorname{sAPP} \beta$ is not involved in the beneficial functions of sAPP $\alpha$, participating in synapse pruning. $\mathrm{A} \beta$ is secreted through sequential APP cleavage by $\beta$ - and $\gamma$-secretases, resulting in peptides that can range from 39 to 43 amino acids. The $\mathrm{A} \beta$ peptides are catabolized by multiple amyloid degrading enzymes, for example, neprilysin and insulindegrading enzyme [19]. It is the imbalance between the production and clearance of $A \beta$ that triggers its deposition as amyloid plaques. However, several studies suggest that $\mathrm{A} \beta$ has a physiological role in the synapses and its complete removal induces neuronal cell death [20-22]. In addition to the aggregates, $\mathrm{A} \beta$ is also present in soluble oligomeric forms in APP-transgenic mice and human diseased brains [20]. Compared to $\mathrm{A} \beta$ aggregates, the soluble oligomers are highly neurotoxic [23]. Therefore, it is possible that aggregation of $\mathrm{A} \beta$ into plaques is a neuroprotective mechanism that eliminates the toxic oligomeric forms [15].

The normal functions of synapses are impaired during the course of AD. Synapse loss correlates with dementia suggesting that it is important for disease progression and for the degeneration process [24]. Dense plaque deposition causes the surrounding neurites to bend and change trajectory, which can lead to changes in synapse signal transmission. Also, gliosis and oxidative stress are observed in the vicinity of plaques. During normal development of the brain, microglia are involved in synaptic pruning after birth and it is possible that in the diseased $\mathrm{AD}$ brain the recruitment of activated microglia around the plaques participates in the synapse loss [24]. In addition to aggregates, the oligomeric forms of $\mathrm{A} \beta$ obtained from cultured cells or from human $\mathrm{AD}$ brain disturb synapses and lead to cognition impairment in injected mice [25-27]. Comparably, evidence also shows that soluble forms of tau are toxic for synapses [28]. The molecular mechanisms that lead to synapse dysfunction and neuronal loss downstream of $\mathrm{A} \beta$ and tau are not completely identified but different pathways are implicated such as mitochondrial dysfunction, oxidative stress, inflammation, and dysregulation of metal homeostasis.

\section{Metals and Metal Binding Proteins Implicated in AD}

Metal ions play essential roles in the brain and there is solid evidence pointing to their homeostatic dysfunction across different neurodegenerative diseases (e.g., [29-31]). This includes the first row transition metals, iron, copper, and zinc and also calcium, whose homeostasis is important for neuronal function and during aging [32-34]. One major hypothesis for this cross talk, which has been put forward since a number of years and which has been elegantly reviewed in [35], proposes that $\mathrm{AD}$ is as much as a metallopathy as a proteinopathy. Indeed, age-related metal ion dysfunction altered levels of neuronal metal ions in $\mathrm{AD}$-affected areas including accumulation in protein deposits, and the interplay between metal ions and $\mathrm{AD}$ pathological proteins indicates a close relationship between protein misfolding, aggregation, and metal ion homeostasis. In $\mathrm{AD}$ patients, it has been shown that $\mathrm{Cu}^{2+}, \mathrm{Zn}^{2+}$, and $\mathrm{Fe}^{2+}$ are found in the core and rims of senile plaques $[36,37]$ and colocalize with $\mathrm{A} \beta[38]$. This has led to the suggestion that metal ion sequestration into plaques could lead to deficient distribution of these metals in the neighbouring regions [39]. Moreover, it is described that in $\mathrm{AD}$ patients $\mathrm{Zn}^{2+}$ is decreased in serum and blood but increased in the cerebrospinal fluid and neocortical tissue [40-42]. In addition, $\mathrm{Zn}^{2+}, \mathrm{Cu}^{2+}$, and $\mathrm{Fe}^{2+}$ are increased in the neuropil of $\mathrm{AD}$ patients $[36,43]$. In agreement with a role of metal ions in pathology, molecules designed to chelate $\mathrm{Zn}^{2+}$ and $\mathrm{Cu}^{2+}$ from amyloid-beta aggregates $[44,45]$ were 


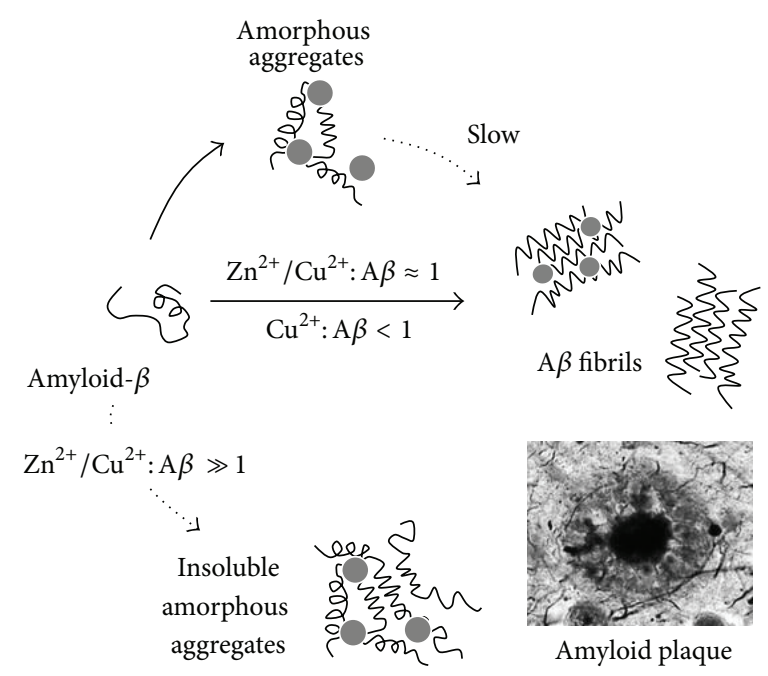

FIGURE 1: Modulation of amyloid- $\beta$ aggregation by $\mathrm{Cu}^{2+}$ and $\mathrm{Zn}^{2+}$ binding. $\mathrm{A} \beta$ aggregation into fibrils is a complex pathway that involves multiple intermediate precursor species. The scheme is a simplification depicting direct effects of $\mathrm{Cu}^{2+}$ and $\mathrm{Zn}^{2+}$ on $\mathrm{A} \beta$ aggregation. Superstoichiometric levels of $\mathrm{Cu}^{2+}$ and $\mathrm{Zn}^{2+}\left(\mathrm{Zn}^{2+} / \mathrm{Cu}^{2+}: \mathrm{A} \beta \gg 1\right)$ result in insoluble and amorphous aggregates rather than organized fibrils, while equimolar $\mathrm{Cu}^{2+}$ and $\mathrm{Zn}^{2+}\left(\mathrm{Zn}^{2+} / \mathrm{Cu}^{2+}: \mathrm{A} \beta \approx 1\right)$ induce amorphous aggregates, which slowly convert to fibrils. At subequimolar $\mathrm{Cu}^{2+}$ levels $\left(\mathrm{Cu}^{2+}: \mathrm{A} \beta<1\right)$, the kinetics of fibril formation are accelerated. The $\mathrm{AD}$ amyloid plaques, depicted in a representation at the bottom right corner of the figure, contain high levels of $\mathrm{Zn}(1055 \mu \mathrm{M}), \mathrm{Fe}(940 \mu \mathrm{M})$, and $\mathrm{Cu}(390 \mu \mathrm{M})$, as reviewed in [35]. See text for details.

found to decrease $\mathrm{A} \beta$ deposits in mice models due to $\mathrm{A} \beta$ solubilisation [45]. Here, as a contribution for a broader molecular and biochemical analysis of protein-metal cross talks in neurodegeneration, we undertake an overview of proteins with metal binding properties which are implicated in $\mathrm{AD}$ (Table 1).

2.1. Amyloid- $\beta$. Metal ions have been acknowledged as important players of the pathological effects of $A \beta$ aggregation in $\mathrm{AD}$ and have been considered as possible modulators of $\mathrm{A} \beta$ misfolding and aggregation due to their binding to the $A \beta$ peptide [46-49] and to amyloid fibrils [50, 51]. $\mathrm{Cu}^{2+}, \mathrm{Zn}^{2+}$, and $\mathrm{Fe}^{2+}$ bind to $\mathrm{A} \beta$ influencing its aggregation pathway and are found in and nearby extracellular senile plaques $[29,36]$. The binding of metal ions to $A \beta$ invariably results in aggregation which may either be into amyloid fibers or into amorphous aggregates, depending on the metal ion, stoichiometry, and environmental conditions [49]. In spite of contradictory findings, there seems to be a consensus that (a) superstoichiometric levels of $\mathrm{Cu}^{2+}$ and $\mathrm{Zn}^{2+}$ result in insoluble and amorphous aggregates rather than organized fibrils [49, 52-55]; (b) equimolar $\mathrm{Zn}^{2+}$ and $\mathrm{Cu}^{2+}$ induce amorphous aggregates, which slowly convert to fibrils [56, 57]; and (c) at subequimolar $\mathrm{Cu}^{2+}$ levels, the kinetics of fibril formation are accelerated [52, 58, 59] (Figure 1). The observation that high levels of $\mathrm{Zn}^{2+}$ and $\mathrm{Cu}^{2+}$ seem to shift aggregation into oligomeric precursors rather than organized fibrils has important consequences in brain function, as these $\mathrm{A} \beta$ precursors are now known to be the neurotoxic selfpropagating species causing neurodegeneration. Furthermore, $\mathrm{Cu}^{2+}$ and $\mathrm{Fe}^{2+}$ participate in ROS production causing oxidative stress and neuronal damage, thus being one of the causes that potentiate $A \beta$ toxicity [60-62]. Indeed, the formation of $\mathrm{H}_{2} \mathrm{O}_{2}$ as a product of the interaction between $\mathrm{A} \beta$ and $\mathrm{Cu}^{2+}$ can generate hydroxyl radicals, which are related to $\mathrm{AD}$ pathology [63]. Superoxide has also been recently shown to be an intermediate of the reaction leading to the production of $\mathrm{H}_{2} \mathrm{O}_{2}$ by $\mathrm{Cu}^{+}-\mathrm{A} \beta$ and $\mathrm{O}_{2}$ [64]. Zinc and copper chelators inhibit $\mathrm{A} \beta$ plaque deposition in $\mathrm{AD}$ patients $[44$, $65,66]$, further suggesting that amyloid pathology may arise from the dysregulation of these metal ions. Excess of iron increases $\mathrm{A} \beta$ production [67] and leads to the formation of annular protofibrils [68] and slows down the formation of ordered cross- $\beta$ fibrils [69] towards the formation of shorter and less ordered aggregates $[53,69]$ which are potentially more toxic.

2.2. Tau. Tau is a disordered cytosolic protein involved in microtubule assembly and stability whose aggregation and toxic deposition are triggered by hyperphosphorylation. This results in the formation of intracellular tau paired helical filaments (PHF), which ultimately gather to form the characteristic neurofibrillary tangles (NFT) $[70,71]$, a process which is modulated by metal ions [30] (Figure 2). $\mathrm{Zn}^{2+}$ binds tau and promotes its hyperphosphorylation [72]; however, low concentrations of zinc induce fibril formation whereas high concentrations induce granular aggregates [73]. $\mathrm{Fe}^{3+}$ also binds to hyperphosphorylated tau and induces its aggregation $[74,75]$, mostly into PHF [75]; however, reduction to $\mathrm{Fe}^{2+}$ can reverse aggregation of tau [75]. Excess of iron is accumulated in NTF $[76,77]$ generating oxidative stress due to the Fenton reaction and perpetuating tau hyperphosphorylation [78]. The role of $\mathrm{Cu}^{2+}$ in tauopathies is controversial. Some studies suggest that tau binds $\mathrm{Cu}^{2+}$ [79], inhibiting its aggregation 


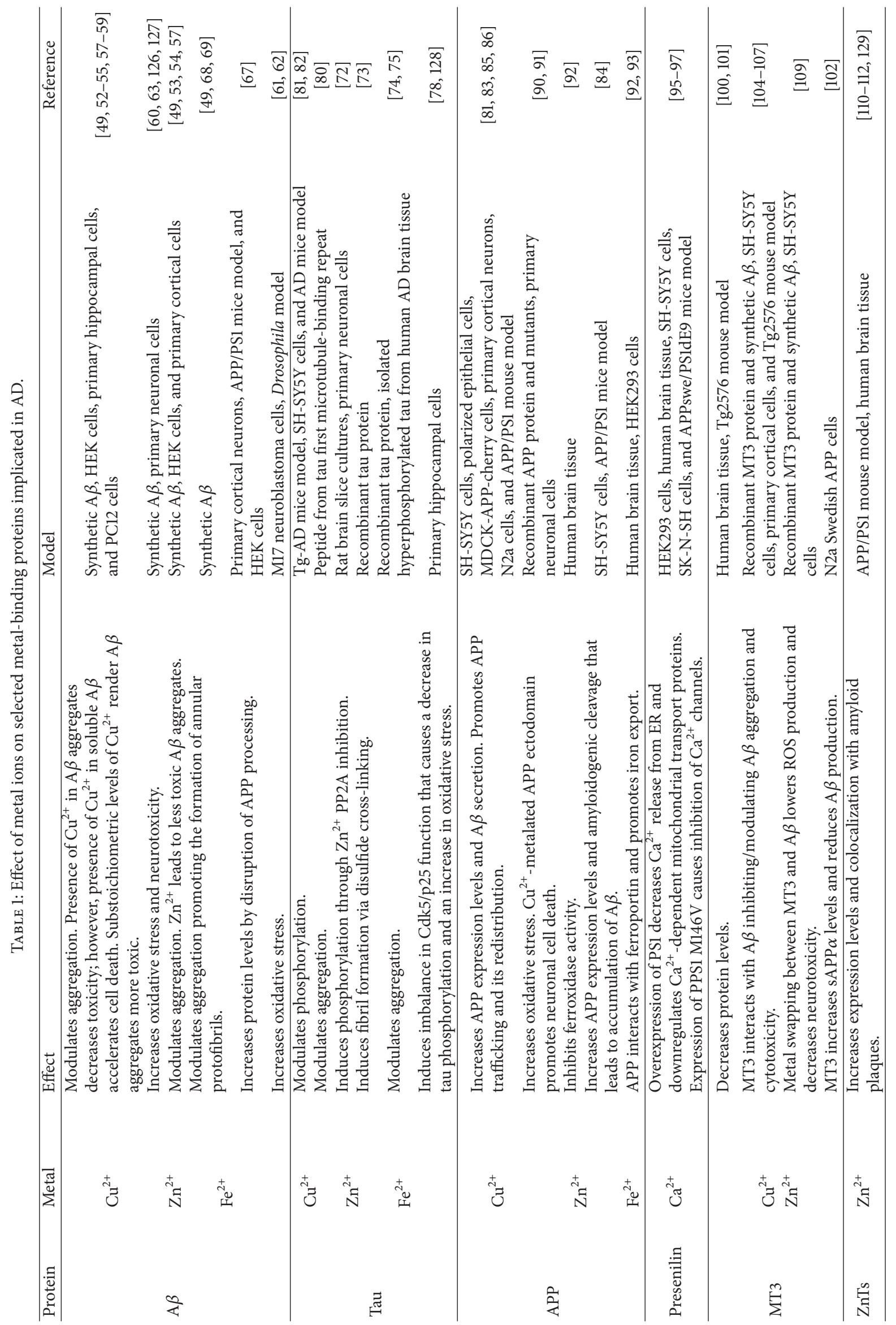




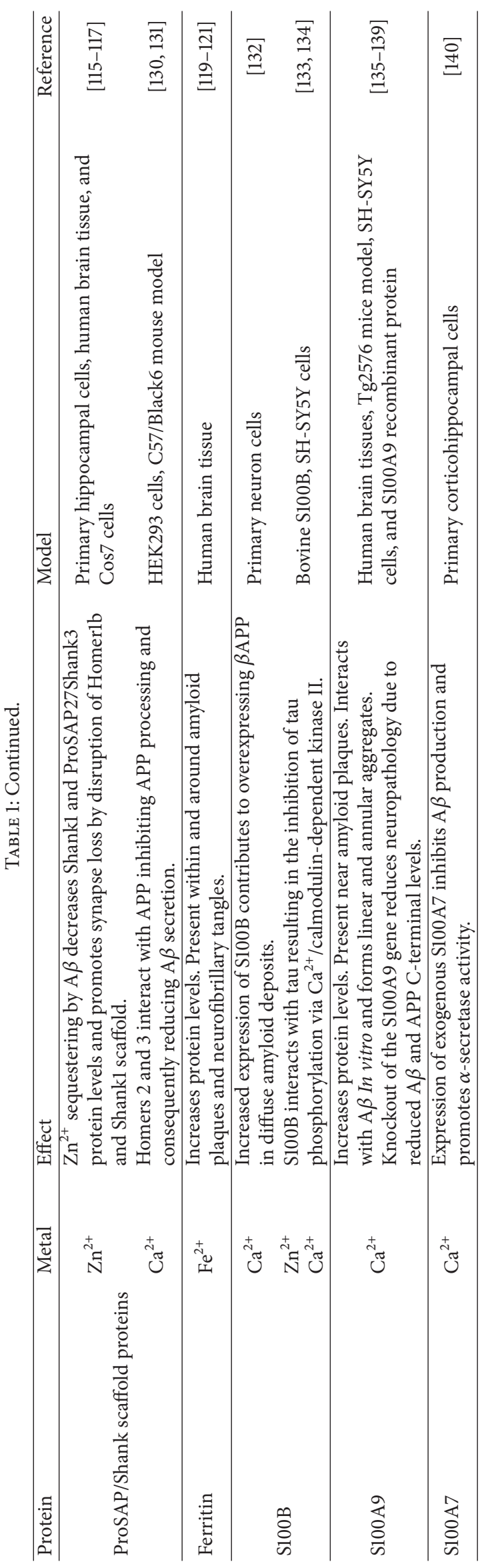




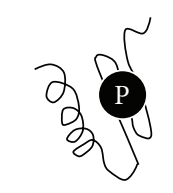

Phosphorylated tau

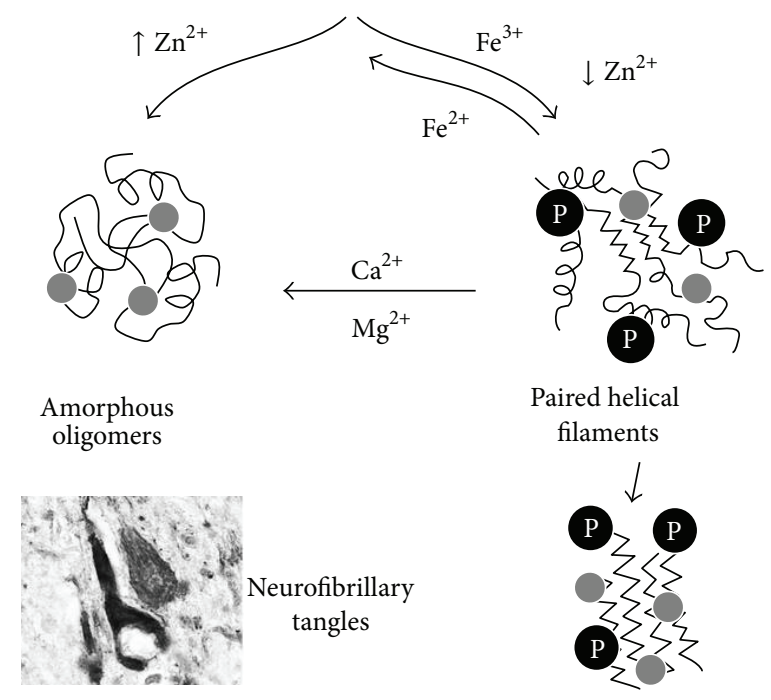

FIGURE 2: Modulation of tau aggregation by metal ions. Hyperphosphorylated (P) tau undergoes aggregation, which is influenced by metal ion binding. Tau phosphorylation facilitates $\mathrm{Fe}^{3+}$ binding that promotes the formation of paired helical filaments (PHF) and further tau fibrillation. The reduction of $\mathrm{Fe}^{3+}$ to $\mathrm{Fe}^{2+}$ reverts $\mathrm{PHF}$ formation. $\mathrm{Zn}^{2+}$ binding at high ratios promotes the formation of amorphous tau oligomers, whereas, at low ratios, PHF are formed. Both $\mathrm{Ca}^{2+}$ and $\mathrm{Mg}^{2+}$ binding to PHF favour the conversion into amorphous off-pathway aggregates. A neurofibrillary tangle is depicted in a representation at the bottom left corner of the figure. See text for details. Adapted from [30].

in vitro [80] while promoting tau hyperphosphorylation in hippocampal neurons [81]. Other studies however suggest that addition of copper-bis(thiosemicarbazone) complexes that increase intracellular copper in AD mice brains inhibits tau phosphorylation [82].

2.3. Amyloid-Beta Precursor Protein. Abnormal processing of the amyloid precursor protein leads to neurotoxic $\mathrm{A} \beta$ production. The proteolytic processing of APP is influenced by metal ions, by protein ligands, and by the APP oligomerization state. $\mathrm{Cu}^{2+}$ and $\mathrm{Zn}^{2+}$ promote APP expression [83-85] and possibly interfere with $\mathrm{A} \beta$ metabolism. $\mathrm{Cu}^{2+}$ enhances APP dimerization and increases extracellular release of $\mathrm{A} \beta$ [86]; yet, other studies suggest that high copper concentrations modulate APP processing leading to reduced $\mathrm{A} \beta$ production [87]. Interestingly, APP contains a copper binding domain and a site that favours $\mathrm{Cu}^{+}$coordination, which has led to the suggestion that it could act as a neuronal metallotransporter [87]. Recent structural and biochemical studies have uncovered a high-affinity binding site within the E2 domain that binds competitively $\mathrm{Cu}^{2+}$ and $\mathrm{Zn}^{2+}$ at physiological concentrations [88]. Metal binding results in large conformational changes and in different structural states that regulate the function of APP and A $\beta$ metabolism [89]. Indeed, APP can be a mediator of $\mathrm{Cu}$ neurotoxicity since it was shown that in primary neuronal cultures APP loaded with $\mathrm{Cu}^{2+}$ induces cell death [90]. This may possibly involve catalytic reduction of $\mathrm{Cu}^{2+}$ to $\mathrm{Cu}^{+}$leading to an increase in oxidative stress in neurons [91]. The links between APP and metal metabolism are further emphasized by the interaction of APP with ferroportin, to promote iron export and its ferroxidase activity $[92,93]$. APP ferroxidase activity is inhibited by $\mathrm{Zn}^{2+}$ binding contributing to $\mathrm{Fe}^{2+}$ accumulation in $\mathrm{AD}$ brains [92].

2.4. Presenilin-1. Presenilin-1 (PS-1) is a component of the $\gamma$-secretase multicomplex, responsible for the cleavage of APP. Presenilins have an activity as low-conductance passive $\mathrm{ER} \mathrm{Ca}^{2+}$ leak channels which is independent of $\gamma$ secretase activity [94]. Overexpression of presenilin results in increased $\mathrm{Ca}^{2+}$ release whose levels are restored by $\gamma$ secretase inhibitors [95]. Mutations in presenilins as in familial $\mathrm{AD}$ forms result in downregulation of $\mathrm{Ca}^{2+}$ channels and $\mathrm{Ca}^{2+}$-dependent mitochondrial transport proteins, strengthening the relationship between $\mathrm{Ca}^{2+}$ homeostasis and presenilin $[94,96,97]$. A recent study based on the effects of metal chelators on $\gamma$-secretase suggests that $\mathrm{Ca}^{2+}$ and $\mathrm{Mg}^{2+}$ stabilize $\gamma$-secretase and enhance its activity [98].

2.5. Metallothionein 3. Metallothioneins are a family of ubiquitous proteins with metal binding properties and antioxidant 
activity [99]. Neuronal metallothionein 3 (MT3), which is involved in the transport and homeostasis of $\mathrm{Zn}^{2+}$ and $\mathrm{Cu}^{2+}$, plays an important role in several AD related pathways. MT3 is decreased in $\mathrm{AD}$ patients [100] and in Tg2576 mice [101], which can lead to aberrant neuritic sprouting [100]. Additionally, MT3 increases sAPP $\alpha$ (soluble amyloid precursor protein $\alpha$ ) levels and reduces $\mathrm{A} \beta$ production [102], through an increase in ADAM10 (a disintegrin and metallopeptidase 10). ADAM10 is a protein responsible for the cleavage of APPderived peptides and activation of the nonamyloidogenic pathway [103]. Mechanistically, it has been reported that the $\beta$-domain of MT3 interacts with $\mathrm{A} \beta$, abolishing $\mathrm{Cu}^{2+}$ mediated aggregation $[104,105]$ and ROS production [104]. It has also been suggested that rapid metal exchange between $\mathrm{Zn}^{2+}-\mathrm{MT} 3$ and $\mathrm{Cu}^{2+}-\mathrm{A} \beta$ [106] or $\mathrm{Zn}^{2+}$ release by MT3 [107] promotes structural changes in $A \beta$ aggregates. In agreement with this, in primary neuron cultures, MT3 inhibits the formation of toxic $A \beta$ aggregates alleviating their neurotoxic effects $[105,108]$. One possible mechanism for this effect may be related to the observed metal swapping between MT3 and soluble and aggregated $\mathrm{A} \beta$, which abolishes the production of Cu-induced ROS [104, 109].

2.6. Zinc Transporter 3. Zinc transporter $3(\mathrm{ZnT3})$ is a synaptic $\mathrm{Zn}^{2+}$ transporter responsible for loading zinc into presynaptic vesicles. This protein is highly expressed in the brains of $\mathrm{AD}$ transgenic mice, in which it colocalizes with amyloid plaques [110-112], where zinc is also found at high concentrations. Zinc sequestering within amyloid plaques has been suggested to provoke an imbalance in the cellular environment with concurrent effects on overall metal metabolism and protein homeostasis [35]. ZnT3 has been shown to decrease with aging and $\mathrm{AD}$, contributing to the aggravation of zinc-mediated cognitive decline [113]. In the AD Tg2576 transgenic mouse model with a ZnT3 knockout, cerebral $\mathrm{A} \beta$ deposition was nearly abolished by the lack of synaptic $\mathrm{Zn}^{2+}[58,59]$. ZnT3 and other zinc transporters, such as ZnTs 1, 4, 5, 6, and 7, are also found upregulated in amyloid plaques of human $\mathrm{AD}$ brains near $\mathrm{Zn}^{2+}$ enriched terminals [60], revealing a cross talk between zinc induced amyloid plaques and zinc transporters. In ZnT3 knockout mice, the addition of metal chaperones results in restoration of expression of the synaptic proteins PSD-95, AMPAR, and NMDAR2b, due to the restitution of hippocampal zinc content [113].

2.7. ProSAP/Shank Scaffold Proteins. ProSAPs/Shanks are zinc-regulated multidomain proteins that are important scaffolding molecules of the postsynaptic density (PSD), a protein dense structure composed of both membranous and cytoplasmic proteins localized at the postsynaptic plasma membrane of excitatory synapses [114]. Deregulation of ProSAP/Shank has been reported in AD: in patients brains and in transgenic mice models, the accumulation of $A \beta$ oligomers is accompanied by reduction of synaptic scaffold protein levels, such as Shank1 and ProSAP2/Shank3 [115], and disruption of the Homerlb and Shank1 scaffolds [116]. Interestingly, sequestration of $\mathrm{Zn}^{2+}$ by $\mathrm{A} \beta$ leads to less mature synapses by decreasing Shankl protein levels at the postsynaptic density in hippocampal neurons [117]. Future studies will further elucidate the mechanistic cross-links between the presence of $\mathrm{A} \beta$, zinc levels, and the scaffolding PSD proteins in the context of AD [118].

2.8. Ferritin. Ferritin is the major intracellular iron storage protein in the body. It has elevated levels in $\mathrm{AD}$ brain tissue [119-121] and is found in the vicinity of AD plaques [120], suggesting that ferritin trapped within the plaque inclusions may block the transport of iron between cells. The loss of integrity of hippocampus tissue of $\mathrm{AD}$ patients is linked with the increase of ferritin [122] and with a reduction of ferroportin protein levels [123]. Effectively, the impact of iron on $\mathrm{AD}$ outcomes is not fully explored but a recent longitudinal study has shown that ferritin is strongly associated with cerebrospinal fluid apolipoprotein E levels; in turn, ferritin is elevated by the Alzheimer's risk allele, APOE$\varepsilon 4$ [124]. This study speculates that the APOE- $\varepsilon 4$ genotype raises the baseline iron load in the $\mathrm{AD}$ brain, lowering the threshold for iron-mediated neuronal loss, a hypothesis that remains to be experimentally addressed.

2.9. S100 Proteins. S100 proteins are a family of at least 21 different vertebrate-specific proteins with two $\mathrm{Ca}^{2+}$-binding EF-hand type sites and in some cases additional sites for $\mathrm{Zn}^{2+}$ and $\mathrm{Cu}^{2+}$ [125]. S100 proteins are part of the inflammatory response and a number of these proinflammatory cytokines (S100B, S100A6, S100A7, S100A1, S100A9, and S100A12) have been implicated in neurodegenerative disorders, such as $\mathrm{AD}$.

$\mathrm{S} 100 \mathrm{~B}$ is a proinflammatory cytokine that triggers glial cell proliferation in a RAGE-dependent manner [141]. RAGE is an immunoglobulin-like cell surface receptor that is upregulated in $\mathrm{AD}$ and triggers the expression of proinflammatory cytokines and mediates $\mathrm{A} \beta$ transport across the bloodbrain barrier [142-144]. At high micromolar concentrations, S100B promotes neuroinflammatory processes and neuronal apoptosis [145]. Increased expression of S100B by plaqueassociated astrocytes in $\mathrm{AD}$ contributes to the appearance of dystrophic neurites overexpressing $\beta$ APP in diffuse amyloid deposits [132]. Astrocytic overexpression of S100B is correlated with the degree of neurite pathology in $A \beta$ aggregates and is induced by interleukin-1 (IL-1), which is secreted by activated microglia present in the plaques [146]. TNF $\alpha$, a cytokine with high levels in $\mathrm{AD}$, decreases $\mathrm{S100B}$ expression in astrocytes but increases its extracellular levels which can lead to RAGE activation [147]. Furthermore, studies demonstrated increased susceptibility to neuroinflammation and neuronal dysfunction after infusion of $A \beta$ in transgenic mice overexpressing S100B [148]. Interestingly, S100B interacts with tau in a $\mathrm{Zn}^{2+}$ dependent fashion that could be responsible for neurite outgrowth [133]. Other studies, however, suggest that the S100B:tau interaction is mediated by $\mathrm{Ca}^{2+} /$ calmodulin-dependent kinase II and results in the inhibition of tau phosphorylation [134].

S100A6, S100A9, and S100A12 also have consistently high levels in samples of AD patients [135, 149]. In particular, S100A9 is found near neuritic plaques $[136,137]$ and was 
found to coaggregate with $\mathrm{A} \beta$ in vitro and form toxic aggregates $[136,138]$. Knockout of S100A9 in a transgenic mouse resulted in reduced $A \beta$ levels in the brain and the animals presented an improved spatial reference memory [139]. In agreement with these observations, knockdown of S100A9 in the AD Tg2576 mice model reduced $\mathrm{A} \beta$ and APP C-terminal levels and decreased BACE activity [137]. Induction of S100A9 levels increased intracellular $\mathrm{Ca}^{2+}$ levels, which in turn upregulated secretion of the inflammatory cytokines IL-1 $\beta$ and TNF $\alpha$ [150]. On the opposite, expression of exogenous S100A7 in primary corticohippocampal neuron cultures derived from Tg2576 transgenic embryos inhibits the generation of $\mathrm{A} \beta$ and promotes the activity of $\alpha$-secretase [140]. Interestingly, S100 proteins have been found to have amyloidogenic properties [151-155]. This feature, along with the high abundance of $\mathrm{S} 100$ proteins in protein deposits, their metal binding properties, dysregulation of $\mathrm{Ca}^{2+}$ signalling, and the high levels of $\mathrm{Cu}^{2+}$ and $\mathrm{Zn}^{2+}$ in the plaques, will certainly translate into the elucidation of new functions of $\mathrm{S} 100$ proteins in $\mathrm{AD}$ pathomechanisms.

\section{Conclusion}

Metal homeostasis and balance depend on a number of biochemical processes and proteins, many of which operate in the neuronal environment and in the extracellular synaptic space or at its interface. The biochemistry of this particular cellular moiety is deeply altered upon aging and under neurodegeneration, with wide changes in protein levels, signalling molecules, and metal ion concentrations. Changes in protein and metal ion homeostasis are hallmark features across amyloid-forming neurodegenerative diseases and as we have here overviewed, a number of proteins implicated in $\mathrm{AD}$ are directly regulated by metal-protein interactions; in some cases, metal ions are even directly involved as modulators of aggregation pathways. Uncovering the mechanistic details of this cross talk at the biochemical levels in respect to effects on synaptic protein networks, $\mathrm{A} \beta$ metabolism and intra- and extracellular protein aggregation in the context of concurrent affected processes such as oxidative stress and neuroinflammation are thus among the major challenges in modern molecular neurosciences.

\section{Conflict of Interests}

The authors declare that there is no conflict of interests regarding the publication of this paper.

\section{Acknowledgments}

This work was supported by the Bial Foundation through grant PT/FB/BL-2014-343 (to CMG), by the Fundação para a Ciência e a Tecnologia through grant PTDC/QUI-BIQ/ 117789/2010 (to CMG), PhD fellowship SFRH/BD/101171/2014 (to JSC), and grant UID/MULTI/04046/2013 from FCT/ MCTES/PIDDAC (to BioISI). CMG is a recipient of a Consolidation Level Investigator FCT, also from the Fundação para a Ciência e a Tecnologia (IF/01046/2014).

\section{References}

[1] D. R. Thal, U. Rüb, M. Orantes, and H. Braak, "Phases of $\mathrm{A} \beta$-deposition in the human brain and its relevance for the development of AD," Neurology, vol. 58, no. 12, pp. 1791-1800, 2002.

[2] R. J. Castellani and G. Perry, "The complexities of the pathology-pathogenesis relationship in Alzheimer disease," Biochemical Pharmacology, vol. 88, no. 4, pp. 671-676, 2014.

[3] R. A. Armstrong, "What causes Alzheimer's disease?" Folia Neuropathologica, vol. 51, no. 3, pp. 169-188, 2013.

[4] C. M. Karch, C. Cruchaga, and A. M. Goate, "Alzheimer's disease genetics: from the bench to the clinic," Neuron, vol. 83, no. 1, pp. 11-26, 2014.

[5] D. H. Kim, S. H. Yeo, J.-M. Park et al., "Genetic markers for diagnosis and pathogenesis of Alzheimer's disease," Gene, vol. 545, no. 2, pp. 185-193, 2014.

[6] I. Piaceri, B. Nacmias, and S. Sorbi, "Genetics of familial and sporadic Alzheimer's disease," Frontiers in Bioscience, vol. 5, no. 1, pp. 167-177, 2013.

[7] A. Goate, M.-C. Chartier-Harlin, M. Mullan et al., "Segregation of a missense mutation in the amyloid precursor protein gene with familial Alzheimer's disease," Nature, vol. 349, no. 6311, pp. 704-706, 1991.

[8] E. Levy-Lahad, W. Wasco, P. Poorkaj et al., "Candidate gene for the chromosome 1 familial Alzheimer's disease locus," Science, vol. 269, no. 5226, pp. 973-977, 1995.

[9] E. I. Rogaev, R. Sherrington, E. A. Rogaeva et al., "Familial Alzheimer's disease in kindreds with missense mutations in a gene on chromosome 1 related to the Alzheimer's disease type 3 gene," Nature, vol. 376, no. 6543, pp. 775-778, 1995.

[10] R. Sherrington, E. I. Rogaev, Y. Liang et al., "Cloning of a gene bearing missense mutations in early-onset familial Alzheimer's disease," Nature, vol. 375, no. 6534, pp. 754-760, 1995.

[11] W. J. Strittmatter, K. H. Weisgraber, D. Y. Huang et al., "Binding of human apolipoprotein $\mathrm{E}$ to synthetic amyloid $\beta$ peptide: isoform-specific effects and implications for late-onset Alzheimer disease," Proceedings of the National Academy of Sciences of the United States of America, vol. 90, no. 17, pp. 80988102, 1993.

[12] J. A. Hardy and G. A. Higgins, "Alzheimer's disease: the amyloid cascade hypothesis," Science, vol. 256, no. 5054, pp. 184-185, 1992.

[13] P. Giannakopoulos, F. R. Herrmann, T. Bussière et al., "Tangle and neuron numbers, but not amyloid load, predict cognitive status in Alzheimer's disease," Neurology, vol. 60, no. 9, pp. 14951500, 2003.

[14] H. Zempel and E. Mandelkow, "Lost after translation: missorting of Tau protein and consequences for Alzheimer disease," Trends in Neurosciences, vol. 37, no. 12, pp. 721-732, 2014.

[15] K. Iqbal, F. Liu, and C.-X. Gong, "Alzheimer disease therapeutics: focus on the disease and not just plaques and tangles," Biochemical Pharmacology, vol. 88, no. 4, pp. 631-639, 2014.

[16] M. Ingelsson, H. Fukumoto, K. L. Newell et al., "Early A $\beta$ accumulation and progressive synaptic loss, gliosis, and tangle formation in AD brain," Neurology, vol. 62, no. 6, pp. 925-931, 2004.

[17] Y. Ling, K. Morgan, and N. Kalsheker, "Amyloid precursor protein (APP) and the biology of proteolytic processing: relevance to Alzheimer's disease," The International Journal of Biochemistry \& Cell Biology, vol. 35, no. 11, pp. 1505-1535, 2003. 
[18] M. Nicolas and B. A. Hassan, "Amyloid precursor protein and neural development," Development, vol. 141, no. 13, pp. 25432548, 2014.

[19] N. N. Nalivaeva, C. Beckett, N. D. Belyaev, and A. J. Turner, "Are amyloid-degrading enzymes viable therapeutic targets in Alzheimer's disease?” Journal of Neurochemistry, vol. 120, no. 1, pp. 167-185, 2012.

[20] L. Mucke and D. J. Selkoe, "Neurotoxicity of amyloid $\beta$ protein: synaptic and network dysfunction," Cold Spring Harbor Perspectives in Medicine, vol. 2, no. 7, Article ID a006338, 2012.

[21] H. A. Pearson and C. Peers, "Physiological roles for amyloid $\beta$ peptides," The Journal of Physiology, vol. 575, no. 1, pp. 5-10, 2006.

[22] L. D. Plant, J. P. Boyle, I. F. Smith, C. Peers, and H. A. Pearson, "The production of amyloid $\beta$ peptide is a critical requirement for the viability of central neurons," The Journal of Neuroscience, vol. 23, no. 13, pp. 5531-5535, 2003.

[23] M. P. Lambert, A. K. Barlow, B. A. Chromy et al., "Diffusible, nonfibrillar ligands derived from Abetal-42 are potent central nervous system neurotoxins," Proceedings of the National Academy of Sciences of the United States of America, vol. 95, no. 11, pp. 6448-6453, 1998.

[24] T. L. Spires-Jones and B. T. Hyman, "The intersection of amyloid beta and Tau at synapses in Alzheimer's disease," Neuron, vol. 82, no. 4, pp. 756-771, 2014.

[25] J. P. Cleary, D. M. Walsh, J. J. Hofmeister et al., "Natural oligomers of the amyloid- $\beta$ protein specifically disrupt cognitive function," Nature Neuroscience, vol. 8, no. 1, pp. 79-84, 2005.

[26] G. M. Shankar, B. L. Bloodgood, M. Townsend, D. M. Walsh, D. J. Selkoe, and B. L. Sabatini, "Natural oligomers of the Alzheimer amyloid- $\beta$ protein induce reversible synapse loss by modulating an NMDA-type glutamate receptor-dependent signaling pathway," The Journal of Neuroscience, vol. 27, no. 11, pp. 2866-2875, 2007.

[27] D. M. Walsh, I. Klyubin, J. V. Fadeeva et al., "Naturally secreted oligomers of amyloid $\beta$ protein potently inhibit hippocampal long-term potentiation in vivo," Nature, vol. 416, no. 6880, pp. 535-539, 2002.

[28] A. M. Pooler, W. Noble, and D. P. Hanger, "A role for tau at the synapse in Alzheimer's disease pathogenesis," Neuropharmacology, vol. 76, pp. 1-8, 2014.

[29] A. I. Bush, “The metallobiology of Alzheimer's disease," Trends in Neurosciences, vol. 26, no. 4, pp. 207-214, 2003.

[30] S. S. Leal, H. M. Botelho, and C. M. Gomes, "Metal ions as modulators of protein conformation and misfolding in neurodegeneration," Coordination Chemistry Reviews, vol. 256, no. 19-20, pp. 2253-2270, 2012.

[31] S. Pfaender and A. M. Grabrucker, "Characterization of biometal profiles in neurological disorders," Metallomics, vol. 6, no. 5, pp. 960-977, 2014.

[32] S. Smaili, H. Hirata, R. Ureshino et al., "Calcium and cell death signaling in neurodegeneration and aging," Anais da Academia Brasileira de Ciencias, vol. 81, no. 3, pp. 467-475, 2009.

[33] P. Egorova, E. Popugaeva, and I. Bezprozvanny, "Disturbed calcium signaling in spinocerebellar ataxias and Alzheimer's disease," Seminars in Cell \& Developmental Biology, vol. 40, pp. 127-133, 2015.

[34] S. S. Leal and C. M. Gomes, "Calcium dysregulation links ALS defective proteins and motor neuron selective vulnerability," Frontiers in Cellular Neuroscience, vol. 9, article 225, 2015.
[35] K. J. Barnham and A. I. Bush, "Biological metals and metaltargeting compounds in major neurodegenerative diseases," Chemical Society Reviews, vol. 43, no. 19, pp. 6727-6749, 2014.

[36] M. A. Lovell, J. D. Robertson, W. J. Teesdale, J. L. Campbell, and W. R. Markesbery, "Copper, iron and zinc in Alzheimer's disease senile plaques," Journal of the Neurological Sciences, vol. 158, no. 1, pp. 47-52, 1998.

[37] P. Zatta, D. Drago, S. Bolognin, and S. L. Sensi, "Alzheimer's disease, metal ions and metal homeostatic therapy," Trends in Pharmacological Sciences, vol. 30, no. 7, pp. 346-355, 2009.

[38] L. M. Miller, Q. Wang, T. P. Telivala, R. J. Smith, A. Lanzirotti, and J. Miklossy, "Synchrotron-based infrared and X-ray imaging shows focalized accumulation of $\mathrm{Cu}$ and $\mathrm{Zn}$ co-localized with $\beta$-amyloid deposits in Alzheimer's disease," Journal of Structural Biology, vol. 155, no. 1, pp. 30-37, 2006.

[39] B. R. Roberts, T. M. Ryan, A. I. Bush, C. L. Masters, and J. A. Duce, "The role of metallobiology and amyloid- $\beta$ peptides in Alzheimer's disease," Journal of Neurochemistry, vol. 120, supplement 1, pp. 149-166, 2012.

[40] H. Basun, L. G. Forssell, L. Wetterberg, and B. Winblad, "Metals and trace elements in plasma and cerebrospinal fluid in normal aging and Alzheimer's disease," Journal of Neural Transmission-Parkinson's Disease and Dementia Section, vol. 3, no. 4, pp. 231-258, 1991.

[41] L. Baum, I. H. S. Chan, S. K.-K. Cheung et al., "Serum zinc is decreased in Alzheimer's disease and serum arsenic correlates positively with cognitive ability," BioMetals, vol. 23, no. 1, pp. 173-179, 2010.

[42] D. Religa, D. Strozyk, R. A. Cherny et al., "Elevated cortical zinc in Alzheimer disease," Neurology, vol. 67, no. 1, pp. 69-75, 2006.

[43] G. M. Bishop, S. R. Robinson, Q. Liu, G. Perry, C. S. Atwood, and M. A. Smith, "Iron: a pathological mediator of Alzheimer disease?" Developmental Neuroscience, vol. 24, no. 2-3, pp. 184$187,2002$.

[44] M. Nguyen, A. Robert, A. Sournia-Saquet, L. Vendier, and B. Meunier, "Characterization of new specific copper chelators as potential drugs for the treatment of alzheimer's disease," Chemistry-A European Journal, vol. 20, no. 22, pp. 6771-6785, 2014.

[45] R. A. Cherny, C. S. Atwood, M. E. Xilinas et al., "Treatment with a copper-zinc chelator markedly and rapidly inhibits $\beta$-amyloid accumulation in Alzheimer's disease transgenic mice," Neuron, vol. 30, no. 3, pp. 665-676, 2001.

[46] C. S. Atwood, R. C. Scarpa, X. Huang et al., "Characterization of copper interactions with Alzheimer amyloid $\beta$ peptides: identification of an attomolar-affinity copper binding site on amyloid $\beta 1-42$," Journal of Neurochemistry, vol. 75, no. 3, pp. 1219-1233, 2000.

[47] D. Noy, I. Solomonov, O. Sinkevich, T. Arad, K. Kjaer, and I. Sagi, "Zinc-amyloid $\beta$ interactions on a millisecond time-scale stabilize non-fibrillar Alzheimer-related species," Journal of the American Chemical Society, vol. 130, no. 4, pp. 1376-1383, 2008.

[48] J. Danielsson, R. Pierattelli, L. Banci, and A. Gräslund, "High-resolution NMR studies of the zinc-binding site of the Alzheimer's amyloid beta-peptide," The FEBS Journal, vol. 274, no. 1, pp. 46-59, 2007.

[49] W.-T. Chen, Y.-H. Liao, H.-M. Yu, I. H. Cheng, and Y.R. Chen, "Distinct effects of $\mathrm{Zn}^{2+}, \mathrm{Cu}^{2+}, \mathrm{Fe}^{3+}$, and $\mathrm{Al}^{3+}$ on amyloid- $\beta$ stability, oligomerization, and aggregation: amyloid$\beta$ destabilization promotes annular protofibril formation," The Journal of Biological Chemistry, vol. 286, no. 11, pp. 9646-9656, 2011. 
[50] C. Talmard, A. Bouzan, and P. Faller, "Zinc binding to amyloid$\beta$ : isothermal titration calorimetry and $\mathrm{Zn}$ competition experiments with Zn sensors," Biochemistry, vol. 46, no. 47, pp. 1365813666, 2007.

[51] S. Parthasarathy, F. Long, Y. Miller et al., "Molecular-level examination of $\mathrm{Cu}^{2+}$ binding structure for amyloid fibrils of 40-residue Alzheimer's beta by solid-state NMR spectroscopy," Journal of the American Chemical Society, vol. 133, no. 10, pp. 3390-3400, 2011.

[52] D. P. Smith, G. D. Ciccotosto, D. J. Tew et al., "Concentration dependent $\mathrm{Cu}^{2+}$ induced aggregation and dityrosine formation of the Alzheimer's disease amyloid- $\beta$ peptide," Biochemistry, vol. 46, no. 10, pp. 2881-2891, 2007.

[53] C. Ha, J. Ryu, and B. P. Chan, "Metal ions differentially influence the aggregation and deposition of Alzheimer's $\beta$-amyloid on a solid template," Biochemistry, vol. 46, no. 20, pp. 6118-6125, 2007.

[54] Y. Yoshiike, K. Tanemura, O. Murayama et al., "New insights on how metals disrupt amyloid beta-aggregation and their effects on amyloid-beta cytotoxicity," The Journal of Biological Chemistry, vol. 276, no. 34, pp. 32293-32299, 2001.

[55] M. Mold, L. Ouro-Gnao, B. M. Wieckowski, and C. Exley, "Copper prevents amyloid-beta(1-42) from forming amyloid fibrils under near-physiological conditions in vitro," Scientific Reports, vol. 3, article 1256, 2013.

[56] A. M. Mancino, S. S. Hindo, A. Kochi, and M. H. Lim, "Effects of clioquinol on metal-triggered amyloid- $\beta$ aggregation revisited," Inorganic Chemistry, vol. 48, no. 20, pp. 9596-9598, 2009.

[57] V. Tõugu, A. Karafin, K. Zovo et al., “ $\mathrm{Zn}(\mathrm{II})$ - and $\mathrm{Cu}(\mathrm{II})$ induced non-fibrillar aggregates of amyloid- $\beta$ (1-42) peptide are transformed to amyloid fibrils, both spontaneously and under the influence of metal chelators," Journal of Neurochemistry, vol. 110, no. 6, pp. 1784-1795, 2009.

[58] C. J. Sarell, S. R. Wilkinson, and J. H. Viles, "Substoichiometric levels of $\mathrm{Cu}^{2+}$ ions accelerate the kinetics of fiber formation and promote cell toxicity of amyloid- $\beta$ from Alzheimer disease," The Journal of Biological Chemistry, vol. 285, no. 53, pp. 41533-41540, 2010.

[59] J. W. Karr and V. A. Szalai, "Cu(II) binding to monomeric, oligomeric, and fibrillar forms of the Alzheimer's disease amyloid- $\beta$ peptide," Biochemistry, vol. 47, no. 17, pp. 5006-5016, 2008.

[60] G. Eskici and P. H. Axelsen, "Copper and oxidative stress in the pathogenesis of Alzheimer's disease," Biochemistry, vol. 51, no. 32, pp. 6289-6311, 2012.

[61] C. A. Rottkamp, A. K. Raina, X. Zhu et al., "Redox-active iron mediates amyloid- $\beta$ toxicity," Free Radical Biology and Medicine, vol. 30, no. 4, pp. 447-450, 2001.

[62] T. Rival, R. M. Page, D. S. Chandraratna et al., "Fenton chemistry and oxidative stress mediate the toxicity of the $\beta$ amyloid peptide in a Drosophila model of Alzheimer's disease," European Journal of Neuroscience, vol. 29, no. 7, pp. 1335-1347, 2009.

[63] D. Jiang, L. Men, J. Wang et al., "Redox reactions of copper complexes formed with different $\beta$-amyloid peptides and their neuropathalogical relevance," Biochemistry, vol. 46, no. 32, pp. 9270-9282, 2007.

[64] K. Reybier, S. Ayala, B. Alies et al., "Free superoxide is an intermediate in the production of $\mathrm{H}_{2} \mathrm{O}_{2}$ by $\mathrm{Cu}(\mathrm{I})$-amyloid- $\beta$ and $\mathrm{O}_{2}, "$ Angewandte Chemie, 2015.

[65] C. W. Ritchie, A. I. Bush, A. Mackinnon et al., "Metal-protein attenuation with iodochlorhydroxyquin (clioquinol) targeting
$\mathrm{A} \beta$ amyloid deposition and toxicity in Alzheimer disease: a pilot phase 2 clinical trial," Archives of Neurology, vol. 60, no. 12, pp. 1685-1691, 2003.

[66] N. G. Faux, C. W. Ritchie, A. Gunn et al., "PBT2 rapidly improves cognition in alzheimer's disease: additional phase II analyses," Journal of Alzheimer's Disease, vol. 20, no. 2, pp. 509516, 2010.

[67] J. Becerril-Ortega, K. Bordji, T. Fréret, T. Rush, and A. Buisson, "Iron overload accelerates neuronal amyloid- $\beta$ production and cognitive impairment in transgenic mice model of Alzheimer's disease," Neurobiology of Aging, vol. 35, no. 10, pp. 2288-2301, 2014.

[68] S. Bolognin, L. Messori, D. Drago, C. Gabbiani, L. Cendron, and P. Zatta, "Aluminum, copper, iron and zinc differentially alter amyloid- $\mathrm{A} \beta_{1-42}$ aggregation and toxicity," The International Journal of Biochemistry \& Cell Biology, vol. 43, no. 6, pp. 877885, 2011.

[69] B. Liu, A. Moloney, S. Meehan et al., "Iron promotes the toxicity of amyloid $\beta$ peptide by impeding its ordered aggregation," The Journal of Biological Chemistry, vol. 286, no. 6, pp. 4248-4256, 2011.

[70] S. Maeda, N. Sahara, Y. Saito et al., "Granular tau oligomers as intermediates of tau filaments," Biochemistry, vol. 46, no. 12, pp. 3856-3861, 2007.

[71] H. Braak and E. Braak, "Neuropathological stageing of Alzheimer-related changes," Acta Neuropathologica, vol. 82, no. 4, pp. 239-259, 1991.

[72] X.-Y. Sun, Y.-P. Wei, Y. Xiong et al., "Synaptic released zinc promotes tau hyperphosphorylation by inhibition of Protein Phosphatase 2A (PP2A)," The Journal of Biological Chemistry, vol. 287, no. 14, pp. 11174-11182, 2012.

[73] Z.-Y. Mo, Y.-Z. Zhu, H.-L. Zhu, J.-B. Fan, J. Chen, and Y. Liang, "Low micromolar zinc accelerates the fibrillization of human Tau via bridging of Cys-291 and Cys-322," The Journal of Biological Chemistry, vol. 284, no. 50, pp. 34648-34657, 2009.

[74] B. Bader, G. Nübling, A. Mehle, S. Nobile, H. Kretzschmar, and A. Giese, "Single particle analysis of tau oligomer formation induced by metal ions and organic solvents," Biochemical and Biophysical Research Communications, vol. 411, no. 1, pp. 190196, 2011.

[75] A. Yamamoto, R. W. Shin, K. Hasegawa et al., "Iron (III) induces aggregation of hyperphosphorylated tau and its reduction to iron (II) reverses the aggregation: implications in the formation of neurofibrillary tangles of Alzheimer's disease," Journal of Neurochemistry, vol. 82, no. 5, pp. 1137-1147, 2002.

[76] D. P. Perl and P. F. Good, "Comparative techniques for determining cellular iron distribution in brain tissues," Annals of Neurology, vol. 32, supplement 1, pp. S76-S81, 1992.

[77] M. A. Smith, P. L. R. Harris, L. M. Sayre, and G. Perry, "Iron accumulation in Alzheimer disease is a source of redoxgenerated free radicals," Proceedings of the National Academy of Sciences of the United States of America, vol. 94, no. 18, pp. 98669868, 1997.

[78] R. B. Maccioni, G. Farías, I. Morales, and L. Navarrete, "The revitalized tau hypothesis on Alzheimer's disease," Archives of Medical Research, vol. 41, no. 3, pp. 226-231, 2010.

[79] Q. Ma, Y. Li, J. Du et al., "Copper binding properties of a tau peptide associated with Alzheimer's disease studied by CD, NMR, and MALDI-TOF MS," Peptides, vol. 27, no. 4, pp. 841849, 2006. 
[80] L.-X. Zhou, J.-T. Du, Z.-Y. Zeng et al., "Copper (II) modulates in vitro aggregation of a tau peptide," Peptides, vol. 28, no. 11, pp. 2229-2234, 2007.

[81] M. Kitazawa, D. Cheng, and F. M. Laferla, "Chronic copper exposure exacerbates both amyloid and tau pathology and selectively dysregulates $\mathrm{cdk} 5$ in a mouse model of AD," Journal of Neurochemistry, vol. 108, no. 6, pp. 1550-1560, 2009.

[82] P. J. Crouch, W. H. Lin, P. A. Adlard et al., "Increasing Cu bioavailability inhibits $\mathrm{A} \beta$ oligomers and tau phosphorylation," Proceedings of the National Academy of Sciences of the United States of America, vol. 106, no. 2, pp. 381-386, 2009.

[83] K. M. Acevedo, Y. H. Hung, A. H. Dalziel et al., "Copper promotes the trafficking of the amyloid precursor protein," The Journal of Biological Chemistry, vol. 286, no. 10, pp. 8252-8262, 2011.

[84] C.-Y. Wang, T. Wang, W. Zheng et al., "Zinc overload enhances APP cleavage and $A \beta$ deposition in the Alzheimer mouse brain," PLoS ONE, vol. 5, no. 12, Article ID e15349, 2010.

[85] P. Hou, G. Liu, Y. Zhao et al., “The role of copper and the copperrelated protein CUTA in mediating APP processing and Abeta generation," Neurobiology of Aging, vol. 36, no. 3, pp. 1310-1315, 2015.

[86] Y. Noda, M. Asada, M. Kubota et al., "Copper enhances APP dimerization and promotes A $\beta$ production," Neuroscience letters, vol. 547, pp. 10-15, 2013.

[87] K. J. Barnham, W. J. McKinstry, G. Multhaup et al., "Structure of the Alzheimer's disease amyloid precursor protein copper binding domain. A regulator of neuronal copper homeostasis," The Journal of Biological Chemistry, vol. 278, no. 19, pp. 1740117407, 2003.

[88] L. Spoerri, L. J. Vella, C. L. L. Pham, K. J. Barnham, and R. Cappai, "The amyloid precursor protein copper binding domain histidine residues 149 and 151 mediate APP stability and metabolism," The Journal of Biological Chemistry, vol. 287, no. 32, pp. 26840-26853, 2012.

[89] S. O. Dahms, I. Könnig, D. Roeser et al., "Metal binding dictates conformation and function of the amyloid precursor protein (APP) E2 domain," Journal of Molecular Biology, vol. 416, no. 3, pp. 438-452, 2012.

[90] A. R. White, G. Multhaup, D. Galatis et al., "Contrasting, species-dependent modulation of copper-mediated neurotoxicity by the Alzheimer's disease amyloid precursor protein," The Journal of Neuroscience, vol. 22, no. 2, pp. 365-376, 2002.

[91] A. R. White, G. Multhaup, F. Maher et al., "The Alzheimer's disease amyloid precursor protein modulates copper-induced toxicity and oxidative stress in primary neuronal cultures," The Journal of Neuroscience, vol. 19, no. 21, pp. 9170-9179, 1999.

[92] J. A. Duce, A. Tsatsanis, M. A. Cater et al., "Iron-export ferroxidase activity of $\beta$-amyloid precursor protein is inhibited by zinc in Alzheimer's disease," Cell, vol. 142, no. 6, pp. 857-867, 2010.

[93] R. C. McCarthy, Y.-H. Park, and D. J. Kosman, "sAPP modulates iron efflux from brain microvascular endothelial cells by stabilizing the ferrous iron exporter ferroportin," EMBO Reports, vol. 15, no. 7, pp. 809-815, 2014.

[94] C. Supnet and I. Bezprozvanny, "Presenilins function in ER calcium leak and Alzheimer's disease pathogenesis," Cell Calcium, vol. 50, no. 3, pp. 303-309, 2011.

[95] K. Honarnejad, C. K. E. Jung, S. Lammich, T. Arzberger, H. Kretzschmar, and J. Herms, "Involvement of presenilin holoprotein upregulation in calcium dyshomeostasis of Alzheimer's disease," Journal of Cellular and Molecular Medicine, vol. 17, no. 2, pp. 293-302, 2013.

[96] D. Sepulveda-Falla, A. Barrera-Ocampo, C. Hagel et al., "Familial Alzheimer's disease-associated presenilin-1 alters cerebellar activity and calcium homeostasis," The Journal of Clinical Investigation, vol. 124, no. 4, pp. 1552-1567, 2014.

[97] M. Ryazantseva, K. Skobeleva, and E. Kaznacheyeva, "Familial Alzheimer's disease-linked presenilin-1 mutation M146V affects store-operated calcium entry: does gain look like loss?" Biochimie, vol. 95, no. 7, pp. 1506-1509, 2013.

[98] M. Ho, D. E. Hoke, Y. J. Chua et al., "Effect of metal chelators on $\gamma$-secretase indicates that calcium and magnesium ions facilitate cleavage of Alzheimer amyloid precursor substrate," International Journal of Alzheimer's Disease, vol. 2011, Article ID 950932, 10 pages, 2011.

[99] P. Babula, M. Masarik, V. Adam et al., "Mammalian metallothioneins: properties and functions," Metallomics, vol. 4, no. 8, pp. 739-750, 2012.

[100] W. H. Yu, W. J. Lukiw, C. Bergeron, H. B. Niznik, and P. E. Fraser, "Metallothionein III is reduced in Alzheimer's disease," Brain Research, vol. 894, no. 1, pp. 37-45, 2001.

[101] B. L. Martin, A. M. Tokheim, P. T. McCarthy, B. S. Doms, A. A. Davis, and I. M. Armitage, "Metallothionein-3 and neuronal nitric oxide synthase levels in brains from the Tg2576 mouse model of Alzheimer's disease," Molecular and Cellular Biochemistry, vol. 283, no. 1-2, pp. 129-137, 2006.

[102] B. H. Park, H. G. Kim, S. W. Jin, S.-G. Song, and H. G. Jeong, "Metallothionein-III increases ADAM10 activity in association with furin, $\mathrm{PC7}$, and $\mathrm{PKC} \alpha$ during non-amyloidogenic processing," FEBS Letters, vol. 588, no. 14, pp. 2294-2300, 2014.

[103] K. Endres and F. Fahrenholz, "The role of the antiamyloidogenic secretase ADAM10 in shedding the APP-like proteins," Current Alzheimer Research, vol. 9, no. 2, pp. 157-164, 2012.

[104] Y. Luo, Y. Xu, Q. Bao et al., "The molecular mechanism for human metallothionein-3 to protect against the neuronal cytotoxicity of Abeta(1-42) with $\mathrm{Cu}$ ions," JBIC Journal of Biological Inorganic Chemistry, vol. 18, no. 1, pp. 39-47, 2013.

[105] Y. Irie and W. M. Keung, "Metallothionein-III antagonizes the neurotoxic and neurotrophic effects of amyloid $\beta$ peptides," Biochemical and Biophysical Research Communications, vol. 282, no. 2, pp. 416-420, 2001.

[106] J. T. Pedersen, C. Hureau, L. Hemmingsen et al., "Rapid exchange of metal between $\mathrm{Zn}_{7}$-metallothionein-3 and amyloid- $\beta$ peptide promotes amyloid-related structural changes," Biochemistry, vol. 51, no. 8, pp. 1697-1706, 2012.

[107] J. Durand, G. Meloni, C. Talmard, M. Vašák, and P. Faller, “Zinc release of $\mathrm{Zn}_{7}$-metallothionein-3 induces fibrillar type amyloid$\beta$ aggregates," Metallomics, vol. 2, no. 11, pp. 741-744, 2010.

[108] J.-H. Kim, Y.-P. Nam, S.-M. Jeon, H.-S. Han, and K. Suk, "Amyloid neurotoxicity is attenuated by metallothionein: dual mechanisms at work," Journal of Neurochemistry, vol. 121, no. 5, pp. 751-762, 2012.

[109] G. Meloni, V. Sonois, T. Delaine et al., "Metal swap between Zn7metallothionein-3 and amyloid- $\beta$-Cu protects against amyloid$\beta$ toxicity," Nature Chemical Biology, vol. 4, no. 6, pp. 366-372, 2008.

[110] W. Zheng, T. Wang, D. Yu et al., "Elevation of zinc transporter $\mathrm{ZnT} 3$ protein in the cerebellar cortex of the A $\beta \mathrm{PP} / \mathrm{PS} 1$ transgenic mouse," Journal of Alzheimer's Disease, vol. 20, no. 1, pp. 323-331, 2010. 
[111] L.-H. Zhang, X. Wang, Z.-H. Zheng et al., "Altered expression and distribution of zinc transporters in APP/PS1 transgenic mouse brain," Neurobiology of Aging, vol. 31, no. 1, pp. 74-87, 2010.

[112] J.-Y. Lee, E. Cho, J.-W. Seo, J. J. Hwang, and J.-Y. Koh, "Alteration of the cerebral zinc pool in a mouse model of Alzheimer disease," Journal of Neuropathology and Experimental Neurology, vol. 71, no. 3, pp. 211-222, 2012.

[113] P. A. Adlard, J. Parncutt, V. Lal et al., "Metal chaperones prevent zinc-mediated cognitive decline," Neurobiology of Disease, vol. 81, pp. 196-202, 2015.

[114] S. Okabe, "Molecular anatomy of the postsynaptic density," Molecular and Cellular Neuroscience, vol. 34, no. 4, pp. 503-518, 2007.

[115] E. Pham, L. Crews, K. Ubhi et al., "Progressive accumulation of amyloid- $\beta$ oligomers in Alzheimer's disease and in amyloid precursor protein transgenic mice is accompanied by selective alterations in synaptic scaffold proteins," FEBS Journal, vol. 277, no. 14, pp. 3051-3067, 2010.

[116] F. Roselli, P. Hutzler, Y. Wegerich, P. Livrea, and O. F. X. Almeida, "Disassembly of shank and homer synaptic clusters is driven by soluble b-amyloid 1-40 through divergent NMDAR-dependent signalling pathways," PLoS ONE, vol. 4, no. 6, Article ID e6011, 2009.

[117] A. M. Grabrucker, M. J. Schmeisser, P. T. Udvardi et al., "Amyloid beta protein-induced zinc sequestration leads to synaptic loss via dysregulation of the ProSAP2/Shank3 scaffold," Molecular Neurodegeneration, vol. 6, article 65, 2011.

[118] S. Grabrucker, L. Jannetti, M. Eckert et al., "Zinc deficiency dysregulates the synaptic ProSAP/Shank scaffold and might contribute to autism spectrum disorders," Brain, vol. 137, no. 1, pp. 137-152, 2014.

[119] K. Jellinger, W. Paulus, I. Grundke-Iqbal, P. Riederer, and M. B. H. Youdim, "Brain iron and ferritin in Parkinson's and Alzheimer's diseases," Journal of Neural TransmissionParkinson's Disease and Dementia Section, vol. 2, no. 4, pp. 327340, 1990.

[120] J. R. Connor, S. L. Menzies, S. M. St Martin, and E. J. Mufson, "A histochemical study of iron, transferrin, and ferritin in Alzheimer's diseased brains," Journal of Neuroscience Research, vol. 31, no. 1, pp. 75-83, 1992.

[121] C. Quintana, S. Bellefqih, J. Y. Laval et al., "Study of the localization of iron, ferritin, and hemosiderin in Alzheimer's disease hippocampus by analytical microscopy at the subcellular level," Journal of Structural Biology, vol. 153, no. 1, pp. 42-54, 2006.

[122] E. P. Raven, P. H. Lu, T. A. Tishler, P. Heydari, and G. Bartzokis, "Increased iron levels and decreased tissue integrity in hippocampus of Alzheimer's disease detected in vivo with magnetic resonance imaging," Journal of Alzheimer's Disease, vol. 37, no. 1, pp. 127-136, 2013.

[123] A. A. Raha, R. A. Vaishnav, R. P. Friedland, A. Bomford, and R. Raha-Chowdhury, "The systemic iron-regulatory proteins hepcidin and ferroportin are reduced in the brain in Alzheimer's disease," Acta Neuropathologica Communications, vol. 1, article 55, 2013.

[124] S. Ayton, N. G. Faux, and A. I. Bush, "Ferritin levels in the cerebrospinal fluid predict Alzheimer's disease outcomes and are regulated by APOE," Nature Communications, vol. 6, article 6760, 2015.

[125] R. Donato, B. R. Cannon, G. Sorci et al., "Functions of S100 proteins," Current Molecular Medicine, vol. 13, no. 1, pp. 24-57, 2013.
[126] X. Huang, M. P. Cuajungco, C. S. Atwood et al., "Cu(II) potentiation of Alzheimer a $\beta$ neurotoxicity. Correlation with cell-free hydrogen peroxide production and metal reduction," The Journal of Biological Chemistry, vol. 274, no. 52, pp. 3711137116, 1999.

[127] X. Huang, C. S. Atwood, M. A. Hartshorn et al., "The A $\beta$ peptide of Alzheimer's disease directly produces hydrogen peroxide through metal ion reduction," Biochemistry, vol. 38, no. 24, pp. 7609-7616, 1999.

[128] J. T. Egaña, C. Zambrano, M. T. Nuñez, C. Gonzalez-Billault, and R. B. Maccioni, "Iron-induced oxidative stress modify tau phosphorylation patterns in hippocampal cell cultures," BioMetals, vol. 16, no. 1, pp. 215-223, 2003.

[129] L.-H. Zhang, X. Wang, M. Stoltenberg, G. Danscher, L. Huang, and Z.-Y. Wang, "Abundant expression of zinc transporters in the amyloid plaques of Alzheimer's disease brain," Brain Research Bulletin, vol. 77, no. 1, pp. 55-60, 2008.

[130] E. Kyratzi and S. Efthimiopoulos, "Calcium regulates the interaction of amyloid precursor protein with Homer3 protein," Neurobiology of Aging, vol. 35, no. 9, pp. 2053-2063, 2014.

[131] L. Parisiadou, I. Bethani, V. Michaki, K. Krousti, G. Rapti, and S. Efthimiopoulos, "Homer2 and Homer3 interact with amyloid precursor protein and inhibit A $\beta$ production," Neurobiology of Disease, vol. 30, no. 3, pp. 353-364, 2008.

[132] Y. Li, J. Wang, J. G. Sheng et al., "S100 $\beta$ increases levels of $\beta$-amyloid precursor protein and its encoding mRNA in rat neuronal cultures," Journal of Neurochemistry, vol. 71, no. 4, pp. 1421-1428, 1998.

[133] W. H. Yu and P. E. Fraser, "S100 $\beta$ interaction with tau is promoted by zinc and inhibited by hyperphosphorylation in Alzheimer's disease," Journal of Neuroscience, vol. 21, no. 7, pp. 2240-2246, 2001.

[134] J. Baudier and R. D. Cole, "Interactions between the microtubule-associated tau proteins and S100b regulate tau phosphorylation by the $\mathrm{Ca} 2+/$ calmodulin-dependent protein kinase II," The Journal of Biological Chemistry, vol. 263, no. 12 , pp. 5876-5883, 1988.

[135] C. E. Shepherd, J. Goyette, V. Utter et al., "Inflammatory S100A9 and S100A12 proteins in Alzheimer's disease," Neurobiology of Aging, vol. 27, no. 11, pp. 1554-1563, 2006.

[136] C. Wang, A. G. Klechikov, A. L. Gharibyan et al., "The role of pro-inflammatory S100A9 in Alzheimer's disease amyloidneuroinflammatory cascade," Acta Neuropathologica, vol. 127, no. 4, pp. 507-522, 2014.

[137] K.-A. Chang, H. J. Kim, and Y.-H. Suh, "The role of S100a9 in the pathogenesis of Alzheimer's disease: the therapeutic effects of S100a9 knockdown or knockout," Neurodegenerative Diseases, vol. 10, no. 1-4, pp. 27-29, 2012.

[138] C. Zhang, Y. Liu, J. Gilthorpe, and J. R. C. van der Maarel, "MRP14 (S100A9) protein interacts with Alzheimer betaamyloid peptide and induces its fibrillization," PLOS ONE, vol. 7, no. 3, Article ID e32953, 2012.

[139] H. J. Kim, K.-A. Chang, T.-Y. Ha et al., "S100A9 knockout decreases the memory impairment and neuropathology in crossbreed mice of Tg2576 and S100A9 knockout mice model," PLoS ONE, vol. 9, no. 2, Article ID e88924, 2014.

[140] W. Qin, L. Ho, J. Wang, E. Peskind, and G. M. Pasinetti, "S100A7, a novel Alzheimer's disease biomarker with non-amyloidogenic $\alpha$-secretase activity acts via selective promotion of ADAM-10," PLoS ONE, vol. 4, no. 1, Article ID e4183, 2009.

[141] R. H. Selinfreund, S. W. Barger, W. J. Pledger, and L. J. Van Eldik, "Neurotrophic protein S100 $\beta$ stimulates glial cell proliferation," 
Proceedings of the National Academy of Sciences of the United States of America, vol. 88, no. 9, pp. 3554-3558, 1991.

[142] Z. Cai, N. Liu, C. Wang et al., "Role of RAGE in Alzheimer's Disease," Cellular and Molecular Neurobiology, 2015.

[143] S. D. Yan, X. Chen, J. Fu et al., "RAGE and amyloid- $\beta$ peptide neurotoxicity in Alzheimer's disease," Nature, vol. 382, no. 6593, pp. 685-691, 1996.

[144] R. Deane, S. D. Yan, R. K. Submamaryan et al., "RAGE mediates amyloid- $\beta$ peptide transport across the blood-brain barrier and accumulation in brain," Nature Medicine, vol. 9, no. 7, pp. 907913, 2003.

[145] L. J. Van Eldik and M. S. Wainwright, "The Janus face of glial-derived S100B: beneficial and detrimental functions in the brain," Restorative Neurology and Neuroscience, vol. 21, no. 3-4, pp. 97-108, 2003.

[146] R. E. Mrak and W. S. T. Griffin, "The role of activated astrocytes and of the neurotrophic cytokine S100B in the pathogenesis of Alzheimer's disease," Neurobiology of Aging, vol. 22, no. 6, pp. 915-922, 2001.

[147] M. M. Edwards and S. R. Robinson, "TNF alpha affects the expression of GFAP and S100B: implications for Alzheimer's disease," Journal of Neural Transmission, vol. 113, no. 11, pp. 1709-1715, 2006.

[148] J. M. Craft, D. M. Watterson, A. Marks, and L. J. Van Eldik, "Enhanced susceptibility of S-100B transgenic mice to neuroinflammation and neuronal dysfunction induced by intracerebroventricular infusion of human $\beta$-amyloid," Glia, vol. 51, no. 3, pp. 209-216, 2005.

[149] A. Boom, R. Pochet, M. Authelet et al., "Astrocytic calcium/zinc binding protein S100A6 over expression in Alzheimer's disease and in PS1/APP transgenic mice models," Biochimica et Biophysica Acta (BBA)-Molecular Cell Research, vol. 1742, no. 1-3, pp. 161-168, 2004.

[150] T.-Y. Ha, K.-A. Chang, J. A. Kim et al., "S100a9 knockdown decreases the memory impairment and the neuropathology in Tg2576 mice, AD animal model," PLoS ONE, vol. 5, no. 1, Article ID e8840, 2010.

[151] T. Vogl, A. L. Gharibyan, and L. A. Morozova-Roche, "Proinflammatory S100A8 and S100A9 proteins: Self-assembly into multifunctional native and amyloid complexes," International Journal of Molecular Sciences, vol. 13, no. 3, pp. 2893-2917, 2012.

[152] S. B. Carvalho, H. M. Botelho, S. S. Leal, I. Cardoso, G. Fritz, and C. M. Gomes, "Intrinsically disordered and aggregation prone regions underlie $\beta$-aggregation in $\$ 100$ proteins," PLOS ONE, vol. 8, no. 10, Article ID e76629, 2013.

[153] S. B. Carvalho, I. Cardoso, H. M. Botelho et al., "Structural heterogeneity and bioimaging of S100 amyloid assemblies," in Bio-Nanoimaging, chapter 18, pp. 197-212, Academic Press, Boston, Mass, USA, 2014.

[154] G. Fritz, H. M. Botelho, L. A. Morozova-Roche, and C. M. Gomes, "Natural and amyloid self-assembly of S100 proteins: structural basis of functional diversity," The FEBS Journal, vol. 277, no. 22, pp. 4578-4590, 2010.

[155] K. Yanamandra, O. Alexeyev, V. Zamotin et al., "Amyloid formation by the pro-inflammatory S100A8/A9 proteins in the ageing prostate," PLoS ONE, vol. 4, no. 5, Article ID e5562, 2009. 


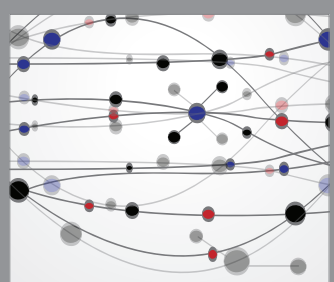

The Scientific World Journal
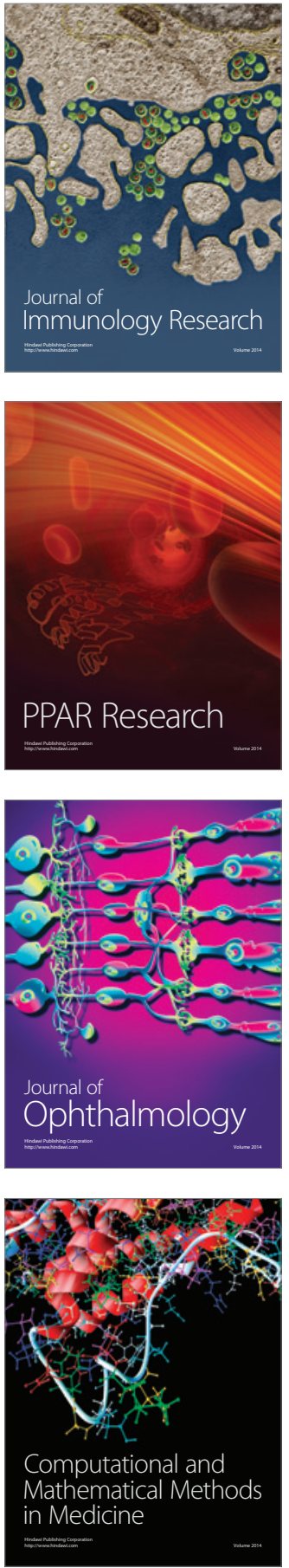

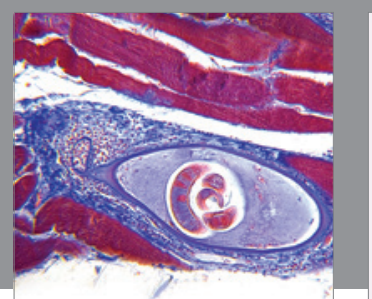

Gastroenterology Research and Practice

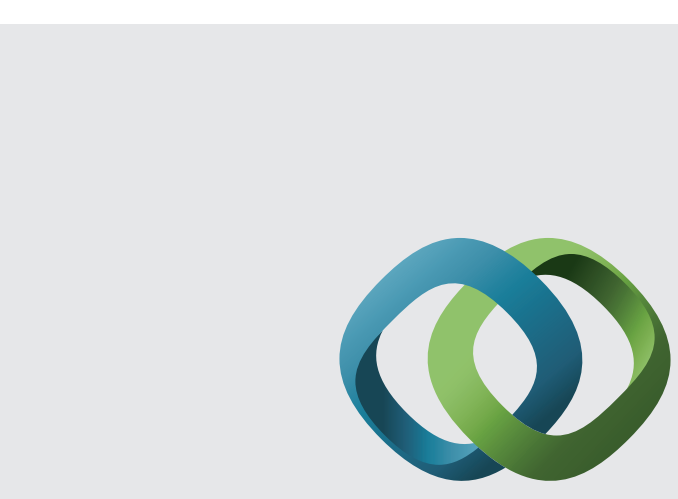

\section{Hindawi}

Submit your manuscripts at

http://www.hindawi.com
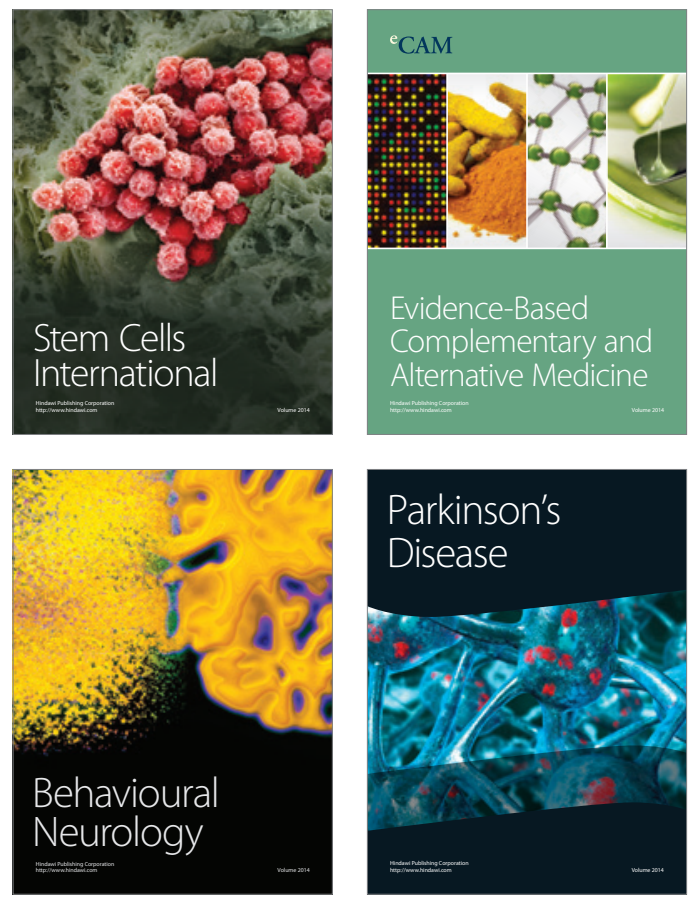
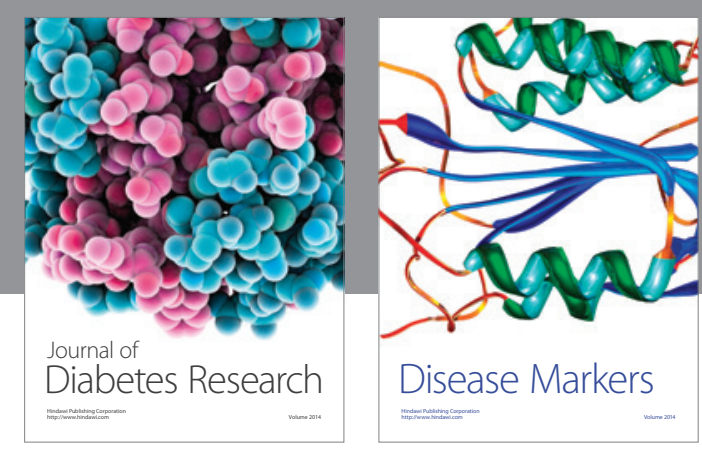

Disease Markers
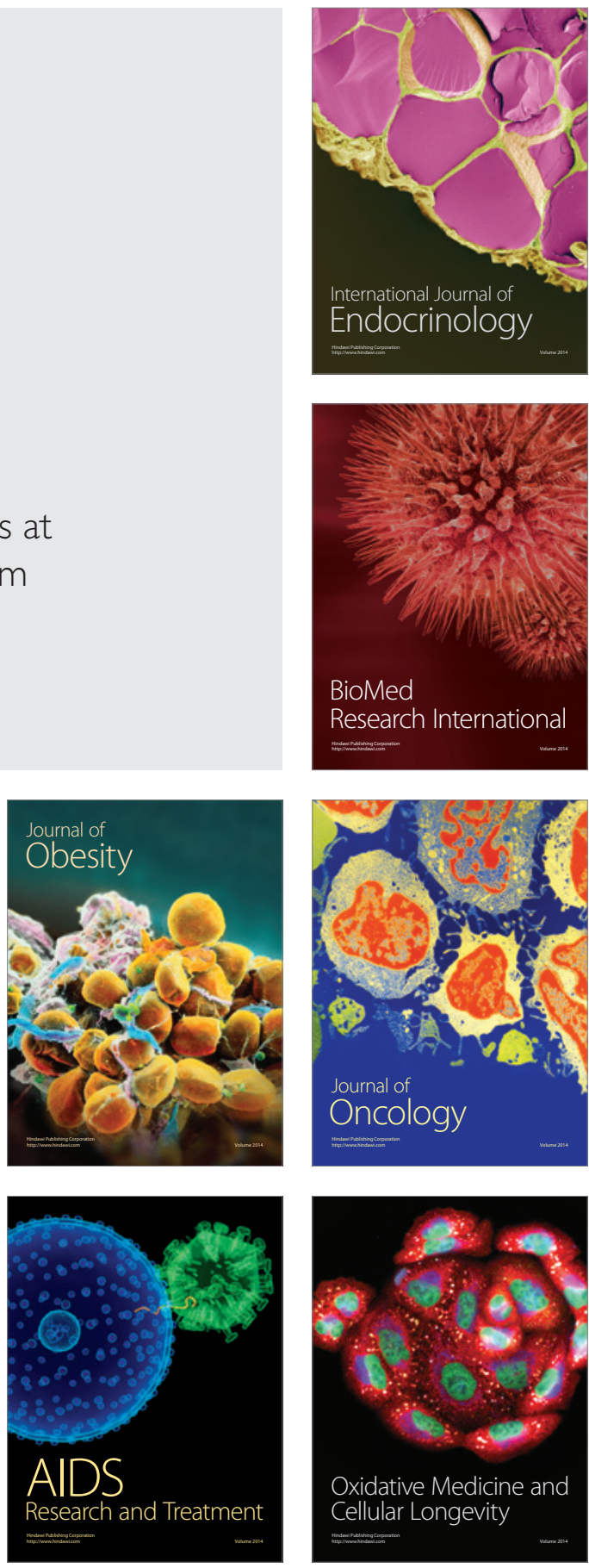